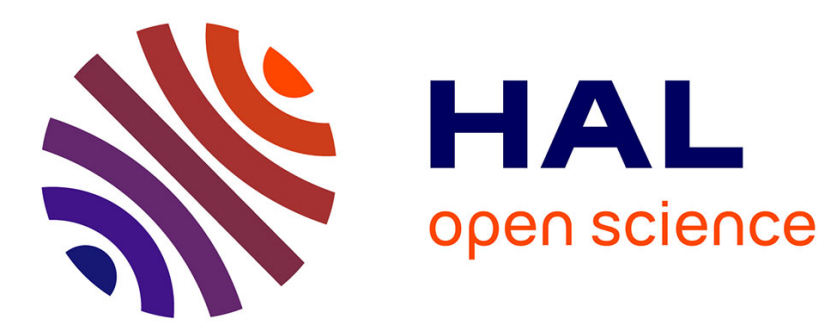

\title{
National media events
}

Sabina Mihelj

\section{To cite this version:}

Sabina Mihelj. National media events. European Journal of Cultural Studies, 2008, 11 (4), pp.471-488. 10.1177/1367549408094983 . hal-00571588

\section{HAL Id: hal-00571588 \\ https://hal.science/hal-00571588}

Submitted on 1 Mar 2011

HAL is a multi-disciplinary open access archive for the deposit and dissemination of scientific research documents, whether they are published or not. The documents may come from teaching and research institutions in France or abroad, or from public or private research centers.
L'archive ouverte pluridisciplinaire HAL, est destinée au dépôt et à la diffusion de documents scientifiques de niveau recherche, publiés ou non, émanant des établissements d'enseignement et de recherche français ou étrangers, des laboratoires publics ou privés. 


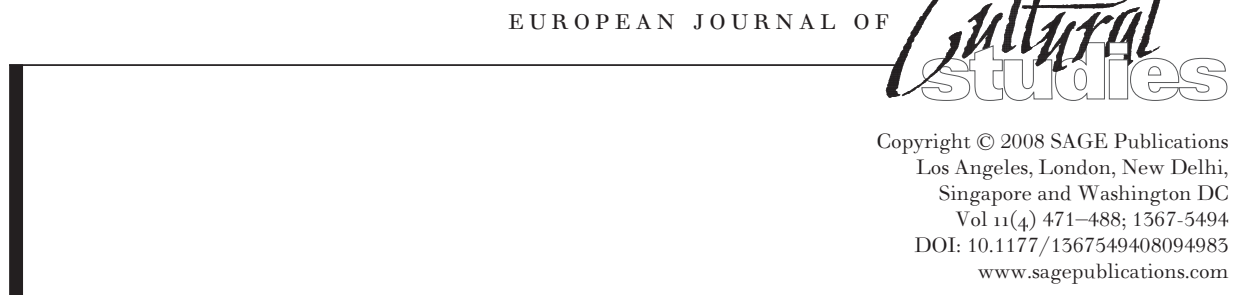

\title{
National media events \\ From displays of unity to enactments \\ of division
}

\section{Sabina Mihelj}

Loughborough University

\begin{abstract}
Despite the conspicuous presence of nationhood and nationalism in existing studies of media events and rituals, explicit conceptualizations of the link between these media phenomena and nationhood remain scarce. Drawing on existing literature and research on the topic, this article proposes to shift attention away from ceremonial occasions primarily aimed at celebrating national unity, towards the more distressing events and mobilization marathons enacting partition and instituting divisions among nations, ethnicities, cultures, races or religions. It provides a series of propositions regarding the involvement of media events in the transformation of audiences into nations, and discusses two categories of media rituals that are linked closely to contemporary forms of national mobilization: rituals of partition and mobilization marathons. Given the disentanglement of nations and states and the multi-ethnic nature of modern states and media spaces, such media occasions ought to receive more sustained attention in the future.
\end{abstract}

KEYWORDS identity, media events, media rituals, nation, national mobilization

From the earliest attempts to study media events and media rituals ${ }^{1}$ (Lang and Lang, 1984[1953]; Merton, 1971[1946]; Shils and Young, 1975[1956]), research often focused on events of national significance. Case studies regularly consider media occasions partaking in nation-building and nationmaintenance, including various rites of passage involving members of royal families (Dayan and Katz, 1985; Phillips, 1999; Wardle and West, 2004) or other national representatives and heroes (McGuigan, 2000; Tsaliki, 1995). Even that most obviously global media event, the Olympic Games, has been shown to achieve its worldwide appeal only by means of mobilizing the waves of competing nationalisms across the globe (Bernstein, 2000; Puijk, 2000; Rowe, 2003). However, despite its conspicuous presence, the link between media events on the one hand, and nations and nationalisms 
on the other hand, so far has received rather meager analytical attention. Daniel Dayan and Elihu Katz's (1992) groundbreaking study is a case in point: although several media events examined in the book entail either reaffirmation or renegotiation of national identity, the authors remain intriguingly silent on the issue (Scannell, 1995a).

On the rare occasions when the existing literature on media events explicitly addresses issues of national identity and nationalism, the theoretical contours of the debate are confined largely to a narrow selection of classic, but also somewhat dated, concepts such as 'imagined com-munity' (Anderson, 1991[1983]) and 'invented tradition' (Hobsbawm and Ranger, 1983). Typically, the main focus is on media rituals which affirm and re-enact existing national beliefs and attachments, and legitimate already established national institutions and balances of power. The fact that media events also may be involved in processes of national identity transformation or deconstruction is largely ignored. A similar preoccupation with national integration transpires also in studies that move beyond an exclusive focus on media events and examine these extraordinary occasions in the broader context of the daily patterning of national life induced by everyday media consumption habits. Radio and television in particular, it is argued, introduced a new kind of 'temporal ordering' of social life (Carey, 1998: 44) and crucially became involved in the construction of a common sense of 'dailiness' (Scannell, 1995b). Broadcasting synthesized various national ceremonies and products from music to literature, transformed them into 'elements of a single corporate national life available to all' (Scannell and Cardiff, 1991: 277), and incorporated them into the cyclical patterning of the broadcast year through weeks, months, seasons and years (see also Scannell, 1995b).

Certainly, many studies expressed scepticism about the actual effects of these attempts at integration, and pointed to the ambiguous, flimsy nature of the abstract national collectivity, to its persisting segmentation along the familiar lines of social division, as well as to the existence of divergent audience responses. Yet these considerations never amounted to an explicit consideration of the role of media events in furthering disintegration or radical transformation. Therefore, in terms of theoretical legacies at work in ritual theory, we could argue that most existing examinations of national media events fall within the reach of the neo-Durkheimian approach to rituals, emphasizing the role of rituals in social integration. In this sense, they have much in common with other attempts to conceptualize media and communication in terms of rituals, and can be conceived as parts of the 'neo-Durkheimian project' in social sciences and humanities (see Alexander, 1988 and Couldry, 2003 for a criticism).

This neo-Durkhemian slant is particularly curious if one considers that several authors have criticized explicitly the overwhelming bias in favour of integrative media events, and instead have examined cases of events centring on social conflict or arising in periods of social 
crisis and transformation (Alexander, 1986; Carey, 1998; Cottle, 2006; Couldry, 2003; Elliott, 1980; Fiske, 1994; Hunt, 1999; Katz and Liebes, 2007; Liebes, 1998; Liebes and Blondheim, 2002, 2005; Yadgar, 2003). These authors often rejected the overly functionalist neo-Durkheimian perspectives, and instead drew their inspiration from the other influential legacy in the anthropology of ritual, largely stemming from the work of Victor Turner. These 'neo-Turnerian' approaches pointed out that media events and rituals are not contributing only to the production and maintenance of social integration, but also are involved in the management of social conflict and change.

Yet these studies only seldom considered how such conflict-ridden, disintegrative and transformative media events relate to issues of nationhood and nationalism. In the rare cases where this was done (Carey, 1998; Yadgar, 2003), the authors again made no reference to recent discussions in nationalism studies. Finally, explorations of media events involved in swift and condensed transformation of collective attachments, such as those arising with mass-scale violent conflicts, radical transformation of political systems or formation of new states, are still virtually non-existent. Whenever an attempt is made to deal with more radical changes and ruptures - as in Dayan and Katz's (1992) analysis of the first broadcasts of the demonstrations in Prague in 1989, Lee et al.'s (2002) examination of Hong Kong's return to China in 1997, or the examinations of media disaster marathons (Liebes, 1998; Liebes and Blondheim, 2002, 2005) and the live broadcasting of other traumatic events (Katz and Liebes, 2007) - the process either is narrated without much recourse to concepts of nation and nationalism, or is forced to fit into theoretical lenses that eschew issues of transformation and end up elucidating only the new status quo. ${ }^{2}$

This article aims to fill this blank by drawing attention to some of the recent debates in nationalism studies, and by using them to discuss transformative and disruptive national media events. To begin with, it is argued that when examining transformative and disruptive national media events, particular attention should be played to the performative role of the audience. The article then discusses the formation of chains of events and their role in national mobilization, and concludes by examining media displays of division. Another caveat is in place here: talking of disruptive or divisive media events - whether national or of another kind - means stretching the definition of media events well beyond that provided by Dayan and Katz (1992), who limit the term to pre-planned, predominantly integrative interruptions of established routines of broadcasting. However, given the proliferation of studies exploring divisive media occasions, it may be time to shift the label of media events to a more general level, and use it to refer to all the different media genres that interrupt the usual daily programming: not only the ceremonial media events explored by Dayan and Katz, but also the disruptive, divisive ones discussed in this article. 


\section{Nation-formation as an episodic process, nation as a contingent event}

Arguably, the lack of literature addressing disruptive national media events is, in part, a consequence of particular weaknesses and omissions in mainstream theories of nations and nationalism. Two closely intertwined issues are at stake. First, for several decades, much of the mainstream debate on nations and nationalism remained overwhelmingly centred on macro-processes and structures fostering the rise and proliferation of national movements and nation-states: the formation of a particular ideology (Kedourie, 1996[1960]), the advent of socio-economic trends such as modernization and industrialization, and the development of specific institutions and infrastructures such as modern states, education systems, transportation and communication networks (Anderson, 1991[1983]; Breuilly, 1993[1982]; Gellner, 1983). However, it was rarely considered that, while indeed enabling the rise of modern nations and nationalisms in general, these macro-factors did not determine their exact form and content. Scholars seldom endeavoured to explain why only some cultural markers rather than others have assumed centre-stage in particular moments and contexts; why only some nations were 'willed' into being, while others entered the annals of history only as fantasies or failures; and why, after all, some nations became wedded to nation-states, while others were assimilated into bigger nations or relegated to the status of 'regional identity' or 'ethnicity'. A similar weakness was shared also by the now-classic works on nationalism and nation-building with respect to social communication (Anderson, 1991[1983]; Deutsch, 1953; Lerner, 1958; Schramm, 1964). While one can easily agree that mass communication is an indispensable means of achieving and maintaining a set of commonalities that transcend the differences within a certain group, it is far less clear why these commonalities should be of one particular type rather than another, and why, more broadly, they should be national rather than of some other kind (Breuilly, 1993[1982]; Schlesinger, 1991).

Second, while much ink has been spent on discussing the early periods of nation-formation, particularly on establishing the exact balance of continuity and discontinuity between modern nations and pre-modern collectivities (Armstrong, 1982; Smith, 1986), we know, comparatively speaking, much less about the ebbs and flows of nations and nationalisms after their initial rise, and about the micro-politics of nationalist mobilization and demobilization in established nations and nation-states. Michael Billig's (1995) study of banal nationalism made a crucial step forward by providing an account of how national attachments are being sustained and reproduced in established national states, via a wide array of hardly noticeable routines and categories that permeate the fabric of everyday life. Several studies followed, diversifying and complicating Billig's theory 
belonging anchored in everyday habits and categories alongside national ones (e.g. Rosie et al., 2004, 2006). Others have shown how the mindlessly performed nation-maintaining practices enter daily lives through a range of communication-related institutions and everyday practices not explored by Billig, for example, national currencies, public phones, advertising and consumption (Foster, 2002), as well as the various media of timekeeping such as wristwatches, clocks and calendars (Postill, 2006).

However, by and large, the theory of banal nationalism has not really challenged the established narrative of nation-formation: its structure has remained largely unilinear, teleological and irreversible. Initially, this narrative ended with the successful establishment of a nation-state, which was expected to attenuate and diffuse nationalist sentiments, if not eliminate them altogether. After Billig's intervention, the narrative was simply extended to include a phase of banal nationalism. Yet as some of the more recent studies of nationalism point out, nation-formation is not necessarily a one-way, cumulative process leading towards a final accomplishment, which is then followed by a hardly noticeable, banal reproduction of national belonging. Instead, this process should be seen as highly uneven and 'episodic' (Hutchinson, 2005), punctuated by short periods of sudden, and rather rare, crystallizations of national feelings on a mass scale (Beissinger, 2002), followed by lengthy periods of 'quiet' or 'banal' nationalism when the continual reconstruction of nationhood is limited to narrow circles of professional nation-builders and nationmaintainers.

For most of the time, then, ideas of fully-fledged nations, homogeneous nation-states and all-embracing national public spheres are precisely that: ideas. Despite the rhetoric of unity and strength, the nationstate is in fact always 'an unfinished project' (Chernilo, 2006: 16). Correspondingly, a nation is 'a contingent, conjecturally fluctuating, and precarious frame of vision and basis for individual and collective action' (Brubaker, 1996: 19), and 'a constantly contested terrain seeking recognition as incontrovertible "social fact" (Beissinger, 2002: 19). In the protracted periods of 'quiet' nationalism, the reality of a nation is limited to the reality of the nation in fabula, constituted by the (often pervasive and institutionalized) categories and frames: categories used to classify individuals as members of nations, frames used in narrating history as a set of parallel national histories, or in representing culture as an ensemble of artefacts, values, norms or habits belonging to individual nations. Therefore it is only in exceptional, brief moments that nations do become what they are normally assumed to be - imagined communities in actu, capturing the hearts and minds of the masses. In this sense, as Mark Beissinger points out, Ernest Renan (2001[1892]) was only half right when he likened nations to daily plebiscites. Nations are indeed, metaphorically speaking, 'plebiscites', but rather than daily plebiscites, they 'are better understood as punctuated and irregular plebiscites' (2002: 25). 
On most occasions, such periodic national mobilizations are carefully pre-planned and managed, scheduled to coincide with national holidays or major sports contests, and therefore used to reassert established attachments. Occasionally, however, the irregular 'plebiscites' of nationhood are prompted by unplanned developments, most often major catastrophes resulting in socio-demographic changes such as war, mass migration or famine, which 'trigger movements from below for or against a particular nation or the nation-state' (Hutchinson (2005: 7). In such extreme circumstances, the processes of nation-maintenance can easily get out of hand, and turn into a process of disintegration or radical transformation, giving rise to new or radically transformed nations. In the past two decades, the whole of Eastern Europe experienced such rapid destruction of existing, long-established routines of nation-maintenance, and their replacement with new ones. In virtually all cases, these developments have been presented as natural and inevitable: typically, the newly-established nationstates have externalized the communist period as an alien intrusion and unwelcome interruption of the natural course of nation-building. Yet clearly, such a retrospective narrative of history - discomfortingly wellattuned to the dominant perception of nation-building as a cumulative, unilinear process - is misguiding. It glosses over precisely what requires explanation: the processes through which established nations and states are challenged, transformed or extinguished. Clearly, such processes can precipitate national media events that have a radically transformative, and sometimes even destructive, intention or effect. The remainder of the article outlines some ideas for understanding and analysing these transformative media occasions.

\section{The role of the audience in transformative national media events}

Given the size of modern nations, national events cannot be truly successful in their identity-building or transformative efforts if they are not supported by modern means of mass communication, which eclipse distances between the physical location of public events and the widely-dispersed locations of addressees. Obviously, not all events involved in identity-construction are made public - on the contrary, a considerable amount goes on behind the stage. Yet every collective identity, and certainly every attempt to change a collective identity, requires also a fair measure of publicity (and thus an audience) if it is to succeed. Particularly when studying national events of a transformative or disruptive character, the role of the audience should be accorded special attention. While most classic studies of media events focus on the performative role of charismatic leaders, it is clear that in several cases the role of the 'hero' is accorded to the audience-turnednation itself. This happens in most national media events, including those 
(Ryfe, 2001). In virtually all such national events, the audience present at the event, as well as the audience following the event through the mass media, is presented and addressed by the media as a nation.

In celebratory media events, members of the audience typically have relatively little influence on the frames used by the reporters, newsreaders and camerapersons when representing them. Their role, although important, is normally prescribed by the organizers of the event and limited to the authentication of the organizers' own vision of the occasion, including any claims that 'the nation', in the form of the audience, is participating in the event. This is consistent with the ideal structure of 'public events of presentation', which does not tolerate ambiguity, discord, inconsistency or challenges (cf. Handelman, 1998). It may well be that the participants of rituals are not all equally convinced of the truth of what is enacted in the ritual (Chaney, 1983) - in our case, the truth of the nation, or the particular form of nationhood staged in the ritual - yet these doubts do not normally become visible in the media coverage unless the media are explicitly looking to delegitimize the event. Instead, the reporters of celebratory events are inclined to interpret the sheer presence of the audience as evidence of belief in, or support for, the values enacted in the ritual. As Roy Rappaport (1999) argued, for a ritual to be effective, participants do not necessarily have to believe that the representations presented to them are accurate, neither do they have to conform, in their everyday lives, to the values and rules that the ritual encodes. However, by the simple fact of performing a ritual, participants signal - in a public manner visible to all - that they accept it; and it is this public acceptance, rather than actual belief and obedience, that is a necessary condition for a ritual to be effective.

Of course, performers can act in a manner which does not conform to prescribed roles, for example, by rejecting a particular vision of the nation suggested by the organizers (Beissinger, 2002). In contrast to the objectified representations of the nation found in texts and museums, and in contrast to regular daily encounters with the media, ceremonial occasions always entail a degree of uncertainty, even if they are not specifically aimed at transformation. Yet if such breaches of suggested roles and order happen, normally the cameras and reporters will turn a blind eye to them, as was the case with overzealous participants, punks and skinheads in the festivities accompanying the British royal wedding in 1981 (Dayan and Katz, 1985). Alternatively, the media may choose to label such game-breakers as devious, and denounce their actions and beliefs as illegitimate and harmful, as is often the case with the media coverage of public protests (see e.g. Hansen and Murdock, 1985). Although nations are always internally contested and incoherent (Askew, 2002; Verdery, 1991), normally these incoherencies are downplayed, ignored or stigmatized. On most occasions, the national 'we' invoked by celebratory media events can accommodate competing and even incompatible definitions of national identity. This 
allows the boundaries of the nation to remain fuzzy in much the same way as in routine references to the nation in everyday media reporting (Rosie et al., 2006).

However, in circumstances of heightened uncertainty and turmoil, the situation is radically different: the competing definitions of the nation become more apparent, and 'the loyalties underlying competing claims to nationhood are put to open test', inviting and even demanding choice between competing forms of identity (Beissinger, 2002: 18). On such occasions, the disruptive behaviour of audiences may simply become too evident, widespread and persistent to be successfully censored, stigmatized or somehow refitted into established frames of reference. Therefore, in contrast with public events of presentation, displays of nationhood in times of crisis always have to play with uncertainty, and as such resemble the ideal structure of events of modelling (cf. Handelman, 1998). In such a situation, ceremonial attempts to re-enact existing national affiliations will fail to provoke what they display as already existing. Therefore, it is imperative that the organizers of media events in such a context deal with the uncertainty unleashed by the nonconformist behaviour of their audiences. If they fail to do that, they may run the risk of having the audience co-opted by rival leaders, particularly if the latter are able to secure the support of the media. Unless they can afford to prevent this by use of force or are prepared to surrender their power to represent, they need to try and reframe their representation in order to co-opt the audience and channel its actions into a particular direction, i.e. to model a particular version of a possible future, a particular resolution to the current state of turmoil and uncertainty.

Media events launched during the disintegration of socialist Yugoslavia provide several examples in point. Towards the late 1980s, federal state institutions became unable to accommodate and co-opt the populations of all the republics, and pan-Yugoslav media events designed to celebrate Yugoslav unity were failing repeatedly. This was due partly to the fact that the the Yugoslav media market was segmented along republican, and thereby mostly national, lines (Snyder, 2002). As the positions of respective republican élites began to drift further apart, audiences across the federation were served diametrically opposed interpretations of the same events. Media responses to the celebrations of a major Yugoslav national holiday in 1990 provide a fitting example. While the holiday continued to be celebrated in a fairly usual way in the Republic of Bosnia and Herzegovina, the Republic of Croatia abolished the holiday altogether. In the Republic of Slovenia, the holiday was still in place, yet the mainstream media took every opportunity to point out how obsolete it was (Mihelj, 2004). Apart from the segmented media market, one of the main reasons for this failure lay in the fact that the celebrations were designed to commemorate the establishment of a federation whose very foundations were being challenged at the time. As such, they failed to 
address the sense of uncertainty and crisis prevailing in the country. In contrast, the most popular republican leaders had discovered long ago the legitimating potential of mass protests, and took every opportunity to channel popular unrest to their own benefit. For example, in the now (in)famous impromptu address delivered in Kosovo in 1987, Slobodan Milošević addressed a crowd of local Serbs and supported their protest against what they perceived as anti-Serb oppression by the Albaniandominated provincial administration (Silber and Little, 1997). Images of the event were broadcast across the federation, installing Milošević as the protector of the Serbian nation.

It is important to note that, during the early stage of Yugoslav disintegration, the participants of mass protests were expressing their grievances in a multitude of different and often poorly articulated ways, and that the nationalist frame was only one among many. Ultimately it was down to professional producers of public representations, including the media and politicians, to promote one or another framing of the event and identify its main actors. For example, the mass protests accompanying a military trial taking place in Slovenia in 1988 were motivated by a mixture of rather incompatible concerns, with some based on universalistic democratic principles, and others on particularistic, nationalist ideals. At the time, some of the mainstream Slovenian media sided with universalistic, prodemocratic concerns, while the Slovenian communist leadership adopted the nationalist line (Mihelj et al., 2007). The mass rallies taking place across Serbia and Montenegro in the same year were also ideologically incoherent, motivated not only by nationalist resentment, but also by class concerns: the protesters were rising against both the nationally undefined 'bureaucracy' and 'red capitalists', as well as against national 'traitors' and members of other Yugoslav nations (Čolović, 2000).

In subsequent years, the nationalist framing became the most popular, sidelining those based on universalistic concerns, as well as those rooted in the supranational identification with the working class. However, during these early protests the exact direction of future developments was still rather uncertain. This internally contested and uncertain identity of mass public events in periods of rapid transformation is something which regularly escapes accounts of historical change. With the benefit of hindsight, even the most dramatic and unexpected changes appear as inevitable consequences of long-existing institutional arrangements and structural constraints. It is rarely considered that such constraints only make a particular course of action possible, not necessary. While transformative events may be spurred by processes that are long underway, they tend to 'transform social relations in ways that could not be fully predicted from the gradual changes that may have made them possible' (Sewell, 1996: 843). In the course of such events, it is up to the actors involved in the event, including the media, to tilt the developments towards one possible course of action rather than another. 


\section{Chains of media events and national mobilization}

Putting emphasis on the transformative, disruptive potential of events may leave the false impression that change can be achieved overnight, within a single event. This is far from the truth. Instead of being magically achieved over the span of one event, large-scale social transformation normally results from a series of interconnected, cascade-like chains of events (Sewell, 1996). Transformative events regularly 'cluster temporally in chains, series, waves, cycles, and tides, forming a punctuated history of heightened challenge and relative stability' (Beissinger, 2002: 17). Within these chains, events themselves begin to guide the course of change, spurring new events and thus contributing to the spread of collective action. Individual events in such chains normally refer to prior events, composing them into a more or less coherent narrative of transformation, as well as constructing a collective memory of the past and promoting visions of what is to come. Thus the multiplicity of options and uncertainty of outcomes apparent while a particular event is taking place is subsequently lost as the event becomes incorporated into a largely unilinear narrative of past transformation.

The military trial that took place in Slovenia in 1988, for example, is now conventionally regarded as the crucial turning point in the early history of Slovenia's democratization, which transformed democratization into an explicitly national project (e.g. Carmichael and Gow, 2000; Pavković, 1997). Yet as noted above, even some of the mainstream media at the time sided with pro-democratic arguments and avoided championing the national cause. In a similar vein, the rallies taking place in Serbia and Montenegro at the same time are viewed now predominantly as instruments that allowed Milošević to replace the authorities in the two autonomous provinces, Vojvodina and Kosovo, as well as the Republic of Montenegro, and thus follow his nationalist agenda (e.g. Cohen, 1995; Silber and Little, 1997). The alternative, a-nationalist framings of the same protests, also present at the time, are either ignored or treated only in passing. The subsequent events have cemented the interpretation of these events as milestones on the path of Serbian and Slovenian nationstate-building.

Such chains, which involve a continuous retrospective appropriation of prior events, can emerge not only across time, but also across space. For example, a nationalist uprising in one geographical location can inspire an analogous course of action in another location, and thereby extend national mobilization into a transnational and transcultural phenomenon (Beissinger, 2002). The fall of communist regimes and rise of nationalist mobilization across Eastern Europe occurred in the form of such a transnational chain. The early openings towards democratization, such as the activities of Solidarność (Solidarity) in Poland, prompted alternative organizations elsewhere in the region to initiate similar activities, including round-table talks in Hungary, the Velvet revolution in Czechoslovakia, protests in 
Bulgaria, etc. Furthermore, this chain of events in Eastern Europe also generated support for protest movements in the Soviet Union (Kramer, 2004). In a similar vein, the movements favouring independence in the Soviet republics of Lithuania, Latvia and Estonia and the Yugoslav republics of Slovenia and Croatia, all closely monitored and to an extent replicated each other's arguments and strategies, including the staging of mass events, the organization of referenda on independence, and the adoption of declarations of independence. On the other hand, the two soonto-be rump federations of Yugoslavia and Russia were also well aware of, and publicly supported, each other's moves including, for example, the deployment of armed forces with the aim of preventing disintegration.

In contemporary societies, such chains of events can hardly be imagined without the contribution of the mass media, which make representations of particular events instantly available to wider audiences, both domestic and foreign. However, in order to understand the dynamics of these tides of events in relation to media events, we need to go beyond the usual study of isolated media events and examine a longer series, or 'tide', of media events building up momentum for change - a series that this article proposes to call a 'mediatized mobilization marathon'. Several authors have struggled to come to terms with the relationship between a self-contained media event and broader, long-term processes, particularly in cases where the events in question were of a markedly transformative character. In a recent systematic overview of various types of media rituals, Simon Cottle suggests the extension of the notion of mediatized rituals to include not only 'event-focused' mediatized rituals, but also those which 'involve a longer term dynamics', exhibit 'narrative progression' and demand 'a more temporally protracted analysis' (2006: 421-4). In a compatible argument, Nick Couldry develops an approach which focuses on 'the ritual space of the media', which is 'the opposite of isolating particular moments and elevating them to special, even "magical" significance', and instead involves 'tracing the antecedents of media rituals in the patterns, categories and boundaries at work everywhere' (2003: 13).

So far, the most often explored media phenomena that are structurally similar to the chains of events examined above are the 'disaster marathons' provoked by unpredictable catastrophes such as 9/11 and Hurricane Katrina (Liebes, 1998; Liebes and Blondheim, 2002, 2005). Instead of attempting to elicit integration and signal reconciliation, argues Liebes (1998), media often react to such occasions by producing extended live coverage continuously staging fear and anxiety. However, unlike the disaster marathons, mobilizational chains of events are not limited to a repetitive staging of fear and chaos (although this is not excluded). Instead, they are attempting explicitly to channel the process of transformation, signalling possible futures and solutions and thereby some form of closure. On such occasions, media tend to engage in either mobilizing or demobilizing support for a particular set of roles and 
plots enacted by various public events. Unlike disaster marathons, such resolution-oriented chains of media events are directed towards a future event or period which is envisaged as a turning point enacting a new order, or a ceremonial closure to present turmoil or restlessness. Media events that form part of such chains engage in a constant marking of the upcoming event or period as an exceptional historic occasion, and continually appropriate and weave together past and present events to form a coherent narrative culminating in the event. Such chains of events also find their counterpart in entirely peaceful, stable contexts, in the tides of interlinked media events raising expectations and mobilizing support before major sports contests or elections. However, in such contexts, the uncertainty is managed carefully and incorporated into the successful unravelling of the chain.

\section{Enactments of division}

The dramatic reconfiguration of collective identity occurring in periods of social crisis often goes beyond attempts at national renewal, reunification and reintegration. If the new, sharpened definition of 'us' no longer embraces everyone as it did before, a simultaneous process of stigmatization, exclusion and expulsion takes place. National mobilization in such circumstances involves choosing to adopt (or reject) a particular form of nationhood at the expense of others, which may result in the expulsion of members adhering to definitions of nationhood not compatible with dominant ones. Therefore the transformative media events accompanying such processes may function as 'marked rite[s] of explicit passage when bodies are stigmatized, reputations destroyed and citizens expelled into a guild of the guilty' (Carey, 1998: 45). Among media occasions examined in the existing literature, cases falling into the category of such disintegrative rituals typically involve media coverage of major court trials (Alexander, 1986; Carey, 1998; Cottle, 2006; Yadgar, 2003). Following James Carey (1998), these occasions can be described as 'rituals of shame, degradation and excommunication'.

It is worth noting that such media trials normally entail a reconfiguration of 'us' that consists of a redefinition of universal values or norms - or at least those that can be universalized. However, many similar events involve a redefinition of belonging based on particular rather than universal criteria, splitting collectives along lines that are perceived as traditional, longstanding and even natural, such as ethnicity, nationality, 'race', religion, culture or civilization. Contrary to rituals of degradation, these events do not centre on shaming and expulsion but on splitting a wider collective into smaller constituents: as such, they can be described as rituals of partition or division. Unlike the more widely-examined rituals of integration, both subsets of disintegrative rituals demarcate identity 
primarily by means of exclusion, defining 'us' mainly in negative terms, in opposition to those who are not 'us' (Yadgar, 2003: 208). Paradoxically, at first sight such events involve integration and disintegration at the same time, splitting the wider collective but uniting subgroups within that wider collective. Besides this basic similarity, important differences between the two categories of events also exist. Rituals of shame, degradation and excommunication are largely mitigated from within one collectivity alone, whose members are engaged in degrading and expelling some of their former co-members, while the latter have little (if any) influence on the process. By contrast, public enactments of division, if successful, need to appeal to at least two, if not more collectivities, which get involved in a mutually reinforcing process of separation.

Recent history offers a multitude of examples of such divisive media events. Reflecting on such events, Elihu Katz and Tamar Liebes (2007) have proposed complementing the typology of media events (Dayan and Katz, 1992) with a four-fold typology of 'traumatic events', including the live broadcasting of terrorist attacks, disasters, wars and potentially protests and revolutions. The distinguishing trait of all traumatic events, they argue, is the element of surprise or shock: although the organizers may be planning the events well in advance, the media and with them the larger public are largely excluded from the preparations, or are provided only very limited access to information. This element of surprise is, in turn, related closely to the second distinguishing characteristic of traumatic media events: the inability of the establishment and media to maintain control over the unfolding of the event (Katz and Liebes, 2007).

However, for a traumatic event to become divisive, another condition must be fulfilled: the collectivities involved in the events need to inhabit separate communicative spaces, which have little tolerance for internal dissent and as such allow for the establishment of diametrically opposed interpretations of the same events. In times of peace and in a media environment that incorporates several checks and balances preventing the monopolization and homogenization of public discourse, such incompatible media renderings of the same event may have few serious repercussions. For example, normally the competing waves of nationalism sparked by global sports contests such as the Olympics, are successfully contained within the ceremonial event itself, and are quickly replaced by the normal, everyday routines of banal nationalism. However, in periods of social crisis, and in contexts amenable to media monopolies and suppression of dissent (Snyder and Ballentine, 1997), such incompatible interpretations can easily precipitate a spiral of mutual retributions, giving rise to a chain of divisive media events.

Usually, divergent interpretations are manifest already at the level of lexical choices performed by producers of such media events: individuals seen as 'terrorists' in one context are named 'freedom fighters' in another; events perceived as acts of 'brutal aggression' in one set of media outlets 
are described as 'legitimate acts of defence' in another. Thus the protest events discussed earlier, occurring in Yugoslavia in the 1980s resulted in entirely different, mutually-exclusive media events in different parts of the federation: for example, while the Serbian media presented the protests taking place during the military trial in Slovenia as 'subversive' and 'counter-revolutionary' (Gow, 1992: 83), Slovenian television continued to emphasize their 'democratic', 'civilized' and 'tolerant' atmosphere (TV Dnevnik 2, TV Ljubljana, 21 June 1988). Without comparing such multiple refractions of the same public event, and its proliferation into a variety of different, sometimes entirely incompatible, media events addressed at different audiences, we are unlikely to understand the full dynamics of divisive media events.

\section{Conclusion}

Drawing on the existing literature and research on media events and rituals, this article aimed to outline a conceptualization of national media events that eschews the usual focus on national integration. Building upon recent debates in nationalism studies, it provided a series of propositions regarding the involvement of national media events in periods of rapid social transformation, and discussed the formation of mobilizational chains of media events as well as the characteristics of media enactments of division. The insistence on the national as a salient category for analysis of media events may seem unusual. It is certainly true that in the case of several contemporary media rituals, including most recent forms such as reality shows (Couldry, 2002), a focus on the national may provide little salient insight. In contemporary fragmented media landscapes, moving increasingly further away from the one-for-all mode of address known from the times of public broadcasting monopoly, even the existence of nations as audiences seems to be slipping away to the ever-more distant, largely invisible and inconsequential background of audience habits and routines. Yet even if the occasions which 'hold the whole nation in its grip' are increasingly rare and limited only to near catastrophe (Katz, 1996: 25), recent disruptions of ordinary media routines, sparked by events such as $9 / 11$ or $7 / 7$, signal that media involvement in national mobilization, and thus also national media events, are here to stay. However, we may need to shift our attention away from ceremonial occasions primarily aimed at celebrating national unity, and towards the more distressing events enacting divisions among nations, ethnicities, cultures, races or religions.

\section{Acknowledgements}

I would like to thank Nick Couldry, Michael Skey, Peter Csigo and the two anonymous reviewers of this journal for their helpful comments on an earlier version of this article. I have also profited from comments provided by the participants of the conference on Media Events: Globalization and Cultural Change, Bremen, July 2007, where I presented some of the ideas discussed in this article. 


\section{Notes}

1. In this article, no distinction is made between media events and media rituals. Arguments developed in the article mostly apply to both.

2. In fact, this blind spot is not limited only to studies of media events per se, but often appears in more general examinations of public events. For example, Don Handelman's $(1998,2004)$ illuminating studies include several insightful discussions of links between the public events of presentation and the bureaucratic logic of modern nation-states, but never mention the links between nationalism and transformative public events events of modelling - in his typology. Handelman even suggests that in modern societies, public events of modelling are limited to kin groups and local communities, while large-scale modern public events fall into the category of events of presentation. While this neat division may apply in times and contexts of relative peace and stability, it becomes inadequate when looking at periods of social crisis, particularly those involving a mobilization or redrawing of national attachments and even state borders.

\section{References}

Alexander, J.C. (1986) 'Cultural Form and Political Substance: The Watergate Hearings as Media Ritual', in S.J. Ball-Rokeach and M.G. Cantor (eds) Media, Audience, and Social Structure, pp. 243-51. Beverly Hills, CA: Sage.

Alexander, J.C. (1988) 'Culture and Political Crisis: "Watergate" and Durkheimian Sociology', in J.C. Alexander (ed.) Durkheimian Sociology: Cultural Studies, pp. 187-224. Cambridge: Cambridge University Press.

Anderson, B. (1991[1983]) Imagined Communities: Reflections on the Origins and Spread of Nationalism (2nd edn). London: Verso.

Armstrong, J. (1982) Nations before Nationalism. Chapel Hill: University of North Carolina Press.

Askew, K.M. (2002) Performing the Nation: Swahili Music and Cultural Politics in Tanzania. Chicago, IL: University of Chicago Press.

Beissinger, M.R. (2002) Nationalist Mobilization and the Collapse of the Soviet State. Cambridge: Cambridge University Press.

Bernstein, A. (2000) “"Things You Can See from There You Can't See from Here": Globalization, Media and the Olympics', Journal of Sport and Social Issues 24(4): 351-69.

Billig, M. (1995) Banal Nationalism. London: Sage.

Breuilly, J. (1993[1982]) Nationalism and the State (2nd edn). Chicago, IL: University of Chicago Press.

Brubaker, R. (1996) Nationalism Reframed: Nationhood and the National Question in the New Europe. Cambridge: Cambridge University Press.

Carey, J.W. (1998) 'Political Ritual on Television: Episodes in the History of Shame, Degradation and Excommunication', in T. Liebes and J. Curran (eds) Media, Ritual and Identity, pp. 42-70. London and New York: Routledge.

Carmichael, C. and J. Gow (2000) Slovenia and the Slovenes: A Small State and the New Europe. Bloomington: Indiana University Press.

Chaney, D. (1983) 'A Symbolic Mirror to Ourselves: Civic Ritual in Mass Society', Media, Culture \& Society 5(2): 119-35.

Chernilo, D. (2006) 'Social Theory's Methodological Nationalism: Myth and Reality', European Journal of Social Theory 9(1): 5-22. 
Cohen, L. (1995) Broken Bonds: Yugoslavia's Disintegration and Balkan Politics in Transition. Boulder, CO: Westview Press.

Čolović, I. (2002) Bordel Ratnika: Folklor, Politika I Rat [Bordel of Warriors: Folklore, Politics and War]. Belgrade: Biblioteka XX Vek and Ćigoja štampa.

Cottle, S. (2006) 'Mediatized Rituals: Beyond Manufacturing Consent', Media, Culture \& Society 28(3): 411-32.

Couldry, N. (2002) 'Playing for Celebrity: Big Brother as Ritual Event', Television \& New Media 3(3): 283-93.

Couldry, N. (2003) Media Rituals: A Critical Approach. London: Routledge.

Dayan, D. and E. Katz (1985) 'Electronic Ceremonies: Television Performs a Royal Wedding', in M. Blonsky (ed.) On Signs: A Semiotics Reader, pp. 16-32. Oxford: Basil Blackwell.

Dayan, D. and E. Katz (1992) Media Events: The Live Broadcasting of History. Cambridge, MA: Harvard University Press.

Deutsch, K.W. (1953) Nationalism and Social Communication: An Inquiry into the Foundations of Nationality. Cambridge, MA: Massachusetts Institute of Technology.

Elliott, P. (1980) 'Press Performance as Political Ritual', in H. Christian (ed.) The Sociology of Journalism and the Press, pp. 141-77. Keele: University of Keele.

Fiske, J. (1994) Media Matters: Race and Gender in US Politics. Minneapolis: University of Minnesota Press.

Foster, R.J. (2002) Materializing the Nation: Commodities, Consumption, and Media in Papua New Guinea. Bloomington: Indiana University Press.

Gellner, E. (1983) Nations and Nationalism. Ithaca, NY: Cornell University Press.

Gow, J. (1992) Legitimacy and the Military: The Yugoslav Crisis. London: Pinter.

Handelman, D. (1998) Models and Mirrors: Towards an Anthropology of Public Events. New York: Berghahn Books.

Handelman, D. (2004) Nationalism and the Israeli State: Bureaucratic Logic and Public Events. New York: Berg.

Hansen, A. and G. Murdock (1985) 'Constructing the Crowd: Populist Discourse and Press Presentation', in V. Mosco and J. Wasko (eds) The Critical Communication Review. Vol. III: Popular Culture and Media Events, pp. 227-57. Norwood, NJ: Ablex.

Hobsbawm, E. and T. Ranger (eds) (1983) The Invention of Tradition. Cambridge: Cambridge University Press.

Hunt, D.M. (1999) O.J. Simpson Facts and Fictions: News Rituals in the Construction of Reality. Cambridge: Cambridge University Press.

Hutchinson, J. (2005) Nations as Zones of Conflict. London: Sage.

Katz, E. (1996) 'And Deliver Us from Segmentation', Annals of the American Academy of Political and Social Science 546(1): 22-33.

Katz, E. and T. Liebes (2007) “"No More Peace!” How Disaster, Terror and War Have Upstaged Media Events', International Journal of Communication 1: 157-66.

Kedourie, E. (1996[1960]) Nationalism. London: Hutchinson.

Kramer, M. (2004) 'The Collapse of East European Communism and the Repercussions within the Soviet Union (Part I)', Journal of Cold War Studies 5(4): 178-256. 
Lang, G. and K. Lang (1984[1953]) 'The Unique Perspective of Television: Macarthur Day', in Politics and Television Re-Viewed, pp. 29-58. Beverly Hills, CA: Sage.

Lee, C.-C., J.M. Chan, Z. Pen and C.Y.K. So (2002) Global Media Spectacle: News War over Hong Kong. New York: State University of New York Press.

Lerner, D. (1958) The Passing of Traditional Society: Modernizing the Middle East. London: Free Press of Glencoe.

Liebes, T. (1998) 'Television's Disaster Marathons: A Danger for Democratic Processes?', in T. Liebes and J. Curran (eds) Media, Ritual and Identity, pp. 71-84. London: Routledge.

Liebes, T. and M. Blondheim (2002) 'Live Television's Disaster Marathon of September 11 and its Subversive Potential', Prometheus 20(3): 271-6.

Liebes, T. and M. Blondheim (2005) 'Myths to the Rescue: How Live Television Intervenes in History', in E.W. Rothenbuhler and M. Coman (eds) Media Anthropology, pp. 188-98. Thousand Oaks, CA: Sage.

McGuigan, J. (2000) 'British Identity and "the People's Princess"', Sociological Review 48(1): 1-18.

Merton, R.K. (1971[1946]) Mass Persuasion: The Social Psychology of a War Bond Drive. Westport, CT: Greenwood.

Mihelj, S. (2004) 'The Role of the Media in the (Re-)Constitution of Nations: The (Re)Constitution of the Slovenian Nation through Mass Media Representations of the Plebiscite for an Independent Slovenia, Bosnian Refugees and Non-Registered Migration, 1990-2001', unpublished PhD thesis, Institutum Studiorum Humanitatis, Ljubljana.

Mihelj, S., V. Bajt and M. Pankov (2007) 'From Defending Democracy to Defending the Nation: Televisual Construction of Collective Identities in the Early Phase of Yugoslav Disintegration', paper presented at the workshop Spinning Out of Control, Belgrade, September.

Pavković, A. (1997) The Fragmentation of Yugoslavia: Nationalism and War in the Balkans. New York: St Martin's.

Phillips, L. (1999) 'Media Discourse and the Danish Monarchy: Reconciling Egalitarianism and Royalism', Media, Culture \& Society 21: 221-45.

Postill, J. (2006) Media and Nation Building: How the Iban Became Malaysian. Oxford: Berghahn Books.

Puijk, R. (2000) 'A Global Media Event? Coverage of the 1994 Lillehammer Olympic Games', International Review for the Sociology of Sport 35(3): 309-30.

Rappaport, R.A. (1999) Ritual and Religion in the Making of Humanity.

Cambridge: Cambridge University Press.

Renan, E. (2001[1892]) 'What is a Nation?', in V. Pecora (ed.) Nations and Identities: Classic Readings, pp. 162-76. Malden, MA: Blackwell.

Rosie, M., P. Petersoo, J. Macinnes, S. Condor and J. Kennedy (2004) 'Nation Speaking unto Nation? National Identity and the Press in the Devolved UK', Sociological Review 52(4): 437-58.

Rosie, M., P. Petersoo, J. Macinnes, S. Condor and J. Kennedy (2006)

'Mediating Which Nation? Citizenship and National Identities in the British Press', Social Semiotics 16(2): 327-44.

Rowe, D. (2003) 'Sport and the Repudiation of the Global', International Review for the Sociology of Sport 38(3): 281-94. 
Ryfe, D.M. (2001) 'From Media Audience to Media Public: A Study of Letters Written in Reaction to FDR's Fireside Chats', Media, Culture \& Society 23(6): 767-81.

Scannell, P. (1995a) 'Media Events', Media, Culture \& Society 17(1): 151-7. Scannell, P. (1995b) Radio, Television and Modern Life. Oxford: Blackwell. Scannell, P. and D. Cardiff (1991) A Social History of British Broadcasting. Vol. 1, 1922-1939: Serving the Nation. Oxford: Basil Blackwell.

Schlesinger, P. (1991) Media, State and Nation. London: Sage.

Schramm, W. (1964) Mass Media and National Development: the Role of Information in the Developing Countries. Stanford, CA: Stanford University Press

Sewell, W.H. (1996) 'Historical Events as Transformations of Structures: Inventing Revolution at the Bastille', Theory and Society 25(6): 841-81. Shils, E. and M. Young (1975[1956]) 'The Meaning of the Coronation', in Center and Periphery: Essays in Macrosociology, pp. 135-52. Chicago, IL: University of Chicago Press.

Silber, L. and A. Little (1997) The Death of Yugoslavia. London: Penguin. Smith, A.D. (1986) The Ethnic Origins of Nations. Oxford: Blackwell. Snyder, J. (2002) From Voting to Violence: Democratization and Violent Conflict. New York: W.W. Norton \& Co.

Snyder, J. and K. Ballantine (1997) 'Nationalism and the Marketplace for Ideas', in M.E. Brown, O.R. Coté, S.M. Lymn-Jones and S.E. Miller (eds) Nationalism and Ethnic Conflict, pp. 61-96. Cambridge, MA: MIT Press.

Tsaliki, L. (1995) 'The Media and the Construction of an "Imagined Community": the Role of Media Events on Greek Television', European Journal of Communication 10(3): 345-70.

Verdery, K. (1991) National Identity under Socialism: Identity and Cultural Politics in Ceausescu's Romania. Berkeley: University of California Press. Wardle, C. and E. West (2004) 'The Press as Agents of Nationalism in the Queen's Golden Jubilee', European Journal of Communication 19(2): 195-214.

Yadgar, Y. (2003) 'A Disintegrating Ritual: The Reading of the Deri Verdict as a Media Event of Degradation', Critical Studies in Mass Communication 20(2): 204-23.

\section{Biographical note}

Sabina Mihelj is a lecturer in media, communication and culture at Loughborough University. Her current research interests include issues of identity and communication, with particular reference to nationalism and religion in multinational settings and border regions. A D D R E S S : Department of Social Sciences, Loughborough University, Loughborough LE113TU, UK.[email: S.Mihelj@lboro.ac.uk] 